\title{
Development of Drought Resistance in Rice
}

\author{
Rishav Kumar* \\ Department of Plant Breeding and Genetics, Bihar Agricultural University, Sabour, \\ Bhagalpur, Bihar-813210, India \\ *Corresponding author
}

\begin{abstract}
A B S T R A C T
Keywords

Drought,

Reproductive stage,

Drought resistant

traits, QTLs

Article Info

Accepted:

12 April 2018

Available Online:

10 May 2018

With the change in the global scenario drought is becoming one of the major problem among other stress and its effect is more severe in rice whose life cycle completely depends on water. Whether it occurs during any stage (early, intermittent and late) it affects crop and its effect is more severe when this stress coincides with reproductive stage of the crop growth. However, rice respond to it by sending signals to shoot which generates signals in terms of physical, chemical and biological form. Hence, screening of plants at this stage is most effective for development of drought resistance. There are several drought resistant traits which have been categorized into primary traits, secondary traits, integrative traits, phenology and plant-type traits. Hence these traits are focussed for the development of drought resistance by adopting conventional and molecular strategy. Varieties like IR-36, IR-64 has been released but through conventional breeding it requires a lot of time to release a variety. Hence molecular strategy has been adopted and focus was given on adopting qtl introgression. Qtls like $\mathrm{qDTY}_{1.1}, \mathrm{qDTY}_{12.1}$ has pronounced effect on yield potential during drought stress. Some of the cases have been also reported that when combination of several qtls used then it showed more pronounced effect during drought stress.
\end{abstract}

\section{Introduction}

Rice is grown worldwide covering most of the tropical countries covering an area of 158.85 million hectares with production 472.1 million tonnes and productivity 29.60 quintals per hectare in 2015-16 (World Agricultural Production, USDA, October, 2016). Globally, it covers $31 \%$ under rainfed lowland condition and $11 \%$ as upland rainfed condition. Rainfed upland and rainfed lowland ecosystems contribute only $21 \%$ of the total production from $38 \%$ of the cropped area (Vikram et al., 2011). More than 2 billion people around the world depend on it for their survival. It is the staple food for more than 3 billion people (Maclean et al., 2002) in Asia, where more than $90 \%$ of the world's rice is produced and consumed (Babu, 2010; Gomez et al., 2010; Sandhu et al., 2014). With the increase in population and to cope up with the demands of growing population there is need to produce more than $40 \%$ of the present to meet the food demand by 2025 (Sandhu et al., 2014; Aravind et al., 2015). By nature it has semiaquatic phylogenetic origin so it depends on ample water supply to complete its lifecycle and thus it is more vulnerable to 
water stress which results in drought stress (Pandey et al., 2007; Kumar et al., 2014; Sabar and Arif, 2014; Saikumar et al., 2014) for reduction in yield. Among other abiotic stress affecting it drought is one of the major limitation for rice production which adversely affects the grain quality in rainfed and upland ecosystems (Yang, 2008; Bimpong et al., 2011; Kumar et al., 2012; Afiukwa et al., 2016). Out of $41 \mathrm{~m}$ ha of the world's rainfed lowland rice area, 95\% lies in Asia where due to erratic and unpredictable rainfall there is drastic reduction in the yield which ranges from 1.0-2.5 tonnes hectare. It is more frequent in unbunded uplands, bunded uplands and shallow rainfed lowland fields as well as in many parts of South and Southeast Asia, sub-Saharan Africa and Latin America (Serraj et al., 2011).In these regions the spatial and temporal variability of rainfall and coarsetextured soils in some parts exposes the rice plants to frequent drought spells. In subSahara African region it occupies about 9 million hectare which is about $84 \%$ of the total rice grown area while in Asia the total drought affected area is 23 million hectare (10 million hectare in upland and 13 million hectare in lowland, Pandey et al., 2005; Usman et al., 2013; Dixit et al., 2014; Kumar et al., 2014; Sellamuthu et al., 2015) with more than half across uplands and rainfed lowlands of India. The 2002 drought in India is described as one of the catastrophic event which reduced rice production by 17 million tons which is about $20 \%$ of the trend value (Pandey et al., 2007). During kharif2009 it leads to reduction of about 11 million tonnes (Babu 2010). The recent drought in 2015-16, leads to the reduction in yield of about 1.17 million tonnes (Annual report G.O.I., 2016-17). The eastern Indo-Gangetic Plain is one of the major, drought-prone rice-producing regions in the world (Huke and Huke, 1997). In this plain, losses due to reproductive-stage drought stress are most severe in the key rice-producing states of eastern India: Chhattisgarh, Orissa,
Jharkhand, Bihar and eastern Uttar Pradesh (Kumar et al., 2014; Kumar et al., 2015). In eastern Indian states especially in Chhattisgarh, Jharkhand and Orissa which are considered to be the major rice growing states approximately about 13.6 million hectare area is drought prone affected which is considered as the largest drought prone affected region among other rainfed regions of the world (Vikram et al., 2016). In severe drought stress the total loss production in Chhattisgarh, Orissa, and Jharkhand have been reported to be as much as $40 \%$, valued at US\$ 650 million (Pandey et al., 2005; Kumar et al., 2014). On an average, the estimated yield lost to drought is $144 \mathrm{~kg} / \mathrm{ha}$ annually in eastern India (Dey and Upadhyaya, 1996). If drought occurs in such a manner then by 2025 , approximately 15-20 million hectares of irrigated rice will experience some degree of water scarcity (Bouman et al., 2007). Many rainfed areas are already drought-prone under present climatic conditions and will experience more intense and more frequent drought events in the future. The green revolution has played a significant role in rice production in irrigated areas but has also limited its impact on rainfed production (Evenson and Gollin, 2003) due to which the gap in yield between irrigated and rainfed rice has increased from 1.7 tonnes per hectare in the late 1960 to 3.6 tonnes per hectare in the late 1990s in Asia (Maclean et al., 2002). The average rice production in eastern India during the normal years still varies between 2-2.5 tonnes per hectare which is still far below the yield potential. High risk in these areas affects severely to small farmers who invests more input on the fertilizers. The overall incidence of poverty is very high in rainfed environment. Although, farmers employ several strategies to cope up with the stress but all goes in vain due to scarcity of rainfall and a consequence farmers has to reduce their food consumption by $15-20 \%$ (Pandey et al., 2007). This income loss directly results in the incidence of poverty. 
After India this loss is followed by Thailand (8.2 million hectare), Bangladesh (5.1 million hectare), Indonesia (4.0 million hectare), Vietnam (2.9 million hectare), Myanmar (2.4 million hectare), Cambodia (1.6 million hectare) and Philippines (1.3 million hectare (Haefele and Hijmans 2007). Drought stress during the vegetative stage greatly reduced the plant growth and development (Farooq et al., 2009). Yield losses ranging from 15 to $50 \%$ has been reported (Srividhya et al., 2011). Chronic dry spells even for a short period affects the crop and it becomes more severe when flowering period coincides with the drought period (Boonjung and Fukai, 1996; Saini and Westgate, 2000; Pantuwan et al., 2002; Lanceras et al., 2004; Venuprasad et al., 2008; Sellamuthu et al., 2011; He and Serraj, 2012; Yadaw et al., 2013; Ha et al., 2016).

\section{Types of drought}

Mainly three types of drought (early, intermittent and late drought stresses) are recognized for rainfed lowland rice on the basis of nature and severity and timing of drought in relation to crop development. In case of early drought there is delayed sowing or transplanting. Yield reductions from early droughts (occurring during vegetative growth, after establishment but before maximum tillering) are often minimal as a result there is only reduction in tiller numbers. Intermittent or continuous droughts (occurs between tillering and flowering) significantly reduces yield despite no apparent drought symptoms (leaf rolling) mainly as a result of reduced leaf expansion and photosynthesis. When drought occurs during later growing stages (panicle initiation and flowering) spikelet fertility is reduced. Terminal drought especially during the flower initiation stage in rice causes severe impact on the yield which on its extreme results in complete failure of crop. Recently, IRRI has given a new classification system according to which there are four major classes of drought prone rainfed environments (1) Early season drought risk in lowland (nonflooded soils and root zone below saturation for at least 10 consecutive days before flowering. (2) Flowering stage drought risk in lowland (non-flooded soils and root zone below saturation for at least 7 days around anthesis). (3) Late season drought risk in lowland (non-flooded soils and root zone below saturation for at least 10 consecutive days after flowering. (4) Flowering stage drought risk in upland (field without rainfall or irrigation for at least 7 days around anthesis and groundwater table deeper than $100 \mathrm{~cm}$ ).

\section{Response of plant to water deficit}

When drought appears numerous changes occurs at the physiological, biochemical and molecular levels (Atkinson and Urwin, 2012; Bargaz et al., 2015). In response to drought conditions roots respond to it by sending signals to the shoot which results in producing various responses like stomatal closure, decrease in leaf expansion and gas exchange. Such types of plant response to water stress can be described in three stages. Stage I occurs when water is freely available and there is no limit in transpiration. Stage II occurs when plants reaches the threshold value of available water and rate of water uptake can't match the potential transpiration rate.

There is decline in transpiration, stomatal conductance, reduction of leaf expansion and growth of the plant (Serraj et al., 1999). In stage III all the metabolic process restricts its activity and no further growth of the plant occurs due to interruption of water flow from the xylem to the surrounding elongating cells. In this stage plants responds by osmotic adjustment and increased production of ABA has been reported (Price et al., 2000; Bimpong et al., 2011) for its survival. Hence, it produces drought adaptation mechanism for its survival (Serraj and Sinclar, 2002). 


\section{Consequences of drought to rice grain formation}

Although drought effect at different stages of the growth of rice plant but its severe form appears when its period strikes with the reproductive stage (Boonjung and Fukai, 1996) resulting in the reduction of spikelet fertility and panicle exertion. Some of the cases have also reported that meiosis in the spore mother cells to fertilization and early seed formation is extremely sensitive to drought which leads to several structural and functional disruptions in reproductive organs, leading to failure of fertilization or premature abortion of the seed (Saini, 1997; Saini and Westgate, 2000). It also inhibits the development of reproductive organs, such as the ovary (Saini et al., 1983) and the pollen at meiosis stage (Saini, 1997). Apart from that it can also inhibit processes such as anther dehiscence, pollen shedding, pollen germination, and fertilization (Satake and Yoshida, 1978; Ekanayake et al., 1990). It has been also found that there is decrease in peduncle elongation, which can ultimately accounts for $70-75 \%$ spikelet sterility under water deficit (O'Toole and Namuco, 1983).

A reduction in grain filling occurs due to a reduction in the assimilate partitioning and activities of sucrose and starch synthesis enzymes (Farooqet al., 2009). Recent studies at IRRI has reported that drought significantly delayed the peduncle elongation, trapped a significant fraction of panicle within the flag leaf sheath due to the repression of the expression of cell-wall invertase genes. The spikelet's left inside the leaf sheath are usually sterile, resulting in a poor yield, which indicates that peduncle elongation may play a major role in panicle exertion and spikelet fertility under stress. Therefore, screening for tolerance at the reproductive stage is considered to be the most fruitful in breeding for improved drought resistance.

\section{Drought resistance trait}

Different types of drought resistant trait have been identified based on the interaction of drought with the rainfed rice field. Such types of drought resistant traits have been categorized into primary traits, secondary traits, integrative traits, phenology and planttype traits. Primary traits includes constitutive traits (rooting depth, root thickness, branching angle and root distribution pattern; Lafitte et al., 2001; Kato et al., 2006) and induced traits (hardpan penetration, cell membrane stability and osmotic adjustment). Constitutive root traits help in the extraction of water from soil during drought stress (Lilley and Fukai, 1994). Secondary trait includes relative water content, leaf water potential, canopy temperature, panicle exertion, leaf death and rolling. Integrative trait includes yield harvest index, spikelet sterility, grain number per panicle, 1000 grain weight, biomass, drought response index, flowering delay. Phenology (flowering) interact with timing of drought has a large effect on yield through integrative traits. Plant-type traits include tiller number and plant height which modify the expression of secondary and integrative traits by affecting transpiration demand. Water deficiency is considered as one of the major challenge for sustainable rice production in future due to progressive climate change processes. Selection and use of these traits in breeding programmes could lead to sustainable production in drought prone regions (Nguyen et al., 1997).

\section{Strategy for improving drought resistance}

\section{Conventional breeding}

Conventional breeding has been based on observed selection for yield. Most of the highyielding varieties- IR36, IR64, MTU1010, BR11, Swarna and Samba Mahsuri are grown in rainfed areas are preferred by the farmers 
due to their yield potential but are not tolerant to drought. These varieties gives high yield during non-drought years, but there is drastic reduction when moderate drought appears and collapse completely in severe drought stress (Kumar et al., 2008).

As yield is a complex character and its improvement depends on several characters which are directly or indirectly associated with it which has been assessed at protein level also (Kumar et al., 2018; Mishra et al., 2018; Kumar et al., 2016; Mishra et al., 2015a, b; Smriti et al., 2015) In the absence of highyielding, good-quality drought-tolerant varieties, farmers in the rainfed ecosystem continue to grow these drought-susceptible varieties. Genetic enhancement of rice for drought tolerance is a cost- effective approach to further increase its productivity, stabilize production and contribute to food security.

The wild species of rice, though phenotypically inferior in agronomic traits, are important reservoirs of many useful genes for drought stress which can be used to improve the cultivated species for these desired traits through breeding (Ali et al., 2010). Several traditionally grown landraces such as KhaoDawk Mali, Azucena, Dular, Rayada, Bala, Apo, Nam Sagui 19, Nagina 22, AdaySel, Dehula, Moroberekan, Huma Wangi Lenggong, Siam Pilihan, ChianungSen Yu, Kashmir Basmati, MR142, FR13A, KDML 105, Azucena and Dular have great adaptability to survive in drought and their hidden genetic potential offers a better opportunity to improve drought tolerance in mega varieties (Pantuwan et al., 2002; Venuprasad et al., 2007; Venuprasad et al., 2009; Henry et al., 2011; Vikram et al., 2012; Swamy and Kumar 2013; Shamsudin et al.,. 2016).

These traditional donors possess genes for better ability to tolerate drought than high- yielding semi-dwarf varieties. Some of the varieties tolerant to drought stress (Azucena from the Philippines and Moroberekan from Guinea) have been reported in japonica varieties from upland ecosystems cultivated in hilly Southeast Asia and Africa (Mackill et al., 1996).

Other varieties which show some degree of resistance to drought reported from plateau region of Eastern India. Nam Sagui 19 reported from Thailand, has both tissue tolerance and grain yielding ability in an indica which is one of the important parental lines in breeding programs. Some of the successful cases of direct selection for grain yield under drought have been reported at IRRI (Kumar et al., 2008; Venuprasad et al., 2008). This breakthrough resulted in the development of several promising breeding lines for the rainfed lowland and upland (Mandal et al., 2010; Verulkar et al., 2010). Some of the varieties of rice for grain yield under drought conditions has been also released through direct selection Sahbhagidhan (India), Sukha dhan-1, Sukha dhan-2 and Sukha dhan-3 (Nepal), BRRI Dhan-56 (Bangladesh), Sahod ulan-3, 5, 6, 8 and Katihan-8 (Philippines), Tarharra 1. These varieties perform well even during favourable years and can provide upto 1 tonnes per hectare under stress.

\section{Marker assisted breeding}

As drought is one of the complex situation which is very difficult to manage through phenotypic selection but it can be managed through transgenics and marker assisted breeding (Collins et al., 2008) which helps to judge more precisely the target trait in same genotype with fewer loss in selection cycle. Many transgenic plants have been developed through introgression of stress related genes to increase tolerance against drought. But due to enhanced expression of these genes plants 
generally shows retarded growth which further limits its practical application (Farooq et al., 2009). The advent of molecular markers has revolutionized the screening of complex traits like drought tolerance in crop plants. Development of molecular markers and their use for the genetic dissection of agronomically important traits has become a powerful approach for studying the inheritance of complex plant traits such as drought tolerance (Suji et al., 2011). The use of molecular markers for the selection of complex breeding traits offers greater selection accuracy with less labour and time inputs and enables assemblage of different target traits into a single cultivar. Molecular markers such as RFLP and SSRis very reliable and have been extensively used in rice (Mohan et al., 1997; Kumar et al., 2015). The very first RFLP map for rice was constructed by McCouch et al., 1988. Microsatellite markers have been also widely applied for rice genome mapping for abiotic stress tolerance (Temnykh et al., 2000). Recent developments in DNA marker technology coupled with MAS provide efficient means to plant breeders to carry out selection of rice cultivars under drought prone environments.

The only prerequisite requirement for effective MAS program is the stable and continued expression of QTLs under different environments. QTLs linked to drought resistance has been mapped in different populations and is found that most of the mapping populations were derived from indica $\mathrm{x}$ japonica parents, in which alleles for drought-resistance traits are contributed by japonica lines. Since indica and japonica ecotypes are grown in different environments so they are used in most of the breeding programs to improve the locally adapted germplasms. Therefore, it is desirable to look for genetic variation among indica ecotypes (IR58821/IR52561; Ali et al., 2000) as well as among japonica ecotypes (Akihikari $\mathrm{x}$
IRAT109, Otomemochi x Yumenohatamochi; Horii et al., 2006; Ikeda et al., 2007) and to map QTLs using populations derived from lines adapted to target environments. Other wild species which acts as a source of suitable donor which can be further used in the breeding programme for developing drought resistant variety are Oryza rufipogon, Oryza australiensis, Oryza glaberrima, Oryza officinalis and Oryza nivara. Several QTLs for yield has been identified in rice for secondary traits associated with drought response including rooting traits (depth, volume, thinness, penetration ability), leaf rolling and death, membrane stability and osmotic adjustment (Lafitte et al., 2006) which has been incorporated into high yielder but drought sensitive variety and has been tested on farmers field (Singh et al., 2009; Thomson et al., 2010; Mackill et al., 2012) plays significant role in developing drought tolerant varieties. Extensive efforts have been made towards the identification of QTLs underlying traits associated with drought tolerance in rice chromosomes using molecular markers. Zheng et al., 2000 identified two QTLs for root penetration ability and root thickness that colocalizes with rice SSR markers RM252 on rice chromosome 4 and RM60 on chromosome 3. Rice QTLs for root growth rate and root penetration ability have also been mapped using RFLP and AFLP markers (Price et al., 2000; Price and Tomas, 1997). The colocation of QTLs for root traits with those of yield under drought has allowed combined selection of both traits (Salunkhe et al., 2011). Courtois et al., 2003 used MAS to transfer a number of QTLs related to deep rooted character from the japonica upland cultivar "Azucena" to the lowland indica variety "IR64". MAS selected lines showed a greater root mass and higher yield in drought stress. Steele et al., 2006 used marker assisted breeding program to improve some root traits related to drought tolerance in an Indian rice cultivar Kalinga III (Table 1-3). 
Table.1 Effect of drought in rice at different stages of the crop growth

\begin{tabular}{|c|c|c|c|}
\hline Crop & Stage & Yield reduction & Reference \\
\hline \multirow{2}{*}{ Rice } & Reproductive (mild stress) & $53-92 \%$ & Lafitte et al., (2007) \\
\cline { 2 - 4 } & Reproductive (severe stress) & $48-94 \%$ & Lafitte et al., (2007) \\
\cline { 2 - 4 } & Grain filling (mild stress) & $30-55 \%$ & Basnayake et al., (2006) \\
\cline { 2 - 4 } & Grain filling (severe stress) & $60 \%$ & Basnayake et al., (2006) \\
\hline & Reproductive & $24-84 \%$ & Venuprasad et al., (2007) \\
\hline
\end{tabular}

\section{Table.2 Traits affecting the drought conditions}

\begin{tabular}{|c|c|c|}
\hline Trait & Function & Reference \\
\hline Deeper, thicker roots & To explore a greater soil volume & Yadav et al., (1997) \\
\hline Root pulling resistance & Root penetration into deeper soil layers & Pantuwan et al., (2002) \\
\hline Greater root penetration ability & To explore a larger soil volume & Ali et al., (2000) \\
\hline Osmotic adjustment & $\begin{array}{l}\text { To allow turgor maintenance at low plant water } \\
\text { potential }\end{array}$ & Lilley et al., (1996) \\
\hline Membrane stability & $\begin{array}{l}\text { Allows leaves to continue functioning at high } \\
\text { temperature }\end{array}$ & Tripathy et al., (2000) \\
\hline Leaf rolling score & Reduce transpiration & Courtois et al., (2000) \\
\hline Leaf relative water content & Indicates maintenance of favourable plant water status & Courtois et al., (2000) \\
\hline Water-use efficiency & $\begin{array}{l}\text { Indicates greater dry weight gain per unit of water lost } \\
\text { by transpiration }\end{array}$ & Specht et al., (2001) \\
\hline
\end{tabular}

Table.3 QTLs obtained from their respective donors

\begin{tabular}{|c|c|c|c|c|c|}
\hline QTL & Donor & Recipient & Marker Interval & $\mathbf{R}^{2}$ & Reference \\
\hline$q D T Y_{1.1}$ & Dhagaddeshi & Swarna & RM431-RM104 & 32 & Ghimire et al., 2012 \\
\hline$q D T Y_{1.1}$ & Dhagaddeshi & IR64 & RM104-RM12091 & 9 & Ghimire et al., 2012 \\
\hline$q D T Y_{1,1}$ & $\mathrm{~N} 22$ & Swarna & RM11943-RM12091 & 13 & Vikram et al., 2011 \\
\hline$q D T Y_{1.1}$ & $\mathrm{~N} 22$ & IR64 & RM11943-RM12091 & 17 & Vikram et al., 2011 \\
\hline$q D T Y_{1.1}$ & $\mathrm{~N} 22$ & MTU1010 & RM11943-RM12091 & 13 & Vikram et al., 2011 \\
\hline$q D T Y_{1.2}$ & Kali Aus & MTU1010 & RM259-RM315 & 7 & Sandhu et al., 2014 \\
\hline$q D T Y_{1.3}$ & Kali Aus & IR64 & RM488-RM315 & 5 & Sandhu et al., 2014 \\
\hline$q D T Y_{2.2}$ & Aday Sel. & IR64 & RM236-RM279 & 11 & Swamy et al., 2013 \\
\hline$q D T Y_{2.2}$ & Kali Aus & MTU1010 & RM211-233A & 16 & Palanog et al., 2014 \\
\hline$q D T Y_{2.3}$ & Kali Aus & IR64 & RM573-RM250 & 9 & Palanog et al., 2014 \\
\hline$q D T Y_{3.1}$ & IR55419-04 & TDK1 & RM168-RM468 & 15 & Dixit et al., 2014 \\
\hline$q$ DTY $_{3.2}$ & Aday Sel. & Sabitri & RM569-RM517 & 23 & Yadaw et al., 2013 \\
\hline$q D T Y_{3,2}$ & $\mathrm{~N}-22$ & Swarna & RM60-RM22 & 19 & Vikram et al., 2011 \\
\hline$q D T Y_{4.1}$ & Aday Sel. & IR64 & RM551-RM16368 & 11 & Swamy et al., 2013 \\
\hline$q D T Y_{6.1}$ & IR55419-04 & TDK1 & RM586-RM217 & 36 & Dixit et al., 2014 \\
\hline$q D T Y_{6.2}$ & IR55419-04 & TDK1 & RM121-RM541 & 20 & Dixit et al., 2014 \\
\hline$q D T Y_{9.1}$ & Aday Sel. & IR64 & RM105-RM434 & 13 & Swamy et al., 2013 \\
\hline$q D T Y_{10.1}$ & MTU1010 & $\mathrm{N} 22$ & RM216-RM304 & 5 & Vikram et al., 2011 \\
\hline $\mathrm{gDTY}_{12.1}$ & Way Rarem & Vandana & RM28048-RM28166 & 12 & Bernier et al., 2007 \\
\hline
\end{tabular}


There are several QTLs governing grain yield under drought conditions has been identified (Bernier et al., 2007; Kumar et al., 2007; Venuprasad et al., 2009; Vikram et al., 2011; Ghimire et al., 2012; Venuprasad et al., 2012; Mishra et al., 2013; Yadaw et al., 2013; Vikram et al., 2016). The development of drought tolerance varieties could be made more efficient through the introgression of drought yield QTLs through marker assisted breeding. This approach has been successfully proven with Vandana lines introgressed with qDTY $_{12.1}$ where production of about $500 \mathrm{~kg}$ $\mathrm{ha}^{-1}$ has been obtained over its donor parent under drought conditions which is similar to Vandana under non-stress condition (Kumar et al., 2014). Efforts have been also made to introgress the identified qDTYs into the drought-susceptible variety IR64 through MAB (Swamy et al., 2013) and it was found that there is yield gain of 10 to $30 \%$ and a yield advantage of 150 to $500 \mathrm{~kg} \mathrm{ha}^{-1}$. However, there is still need of at least 1000 $\mathrm{kg} \mathrm{ha}^{-1}$ to meet the present needs of farmers. Among other QTLS qDTY 12.1 was the first reported large-effect QTL for grain yield under reproductive stage drought (Bernier $e t$ al., 2007). This QTL was identified among 436 random $\mathrm{F}_{3}$-derived lines from a cross between upland rice cultivars Vandana and Way Rarem. This QTL shows $\mathrm{R}^{2}$ of $33 \%$ under severe upland reproductive-stage drought conditions (Kumar et al., 2014) and approximately $23.8 \%$ of the phenotypic variance under severe lowland drought for lowland-adapted variety Sabitri (Mishra et al., 2013). Later on, qDTY 12.1 was also identified to show a similar high effect in lowland reproductive-stage drought in an IR74371-461-1/Sabitri population (Mishra et al., 2013). Another QTL, qDTY 2.1 and qDTY $_{3.1}$ are the two large-effect QTLs affecting grain yield under lowland reproductive-stage drought, were identified in a BIL population derived from a cross between lowland rice variety Swarna and upland rice variety Apo. Both
QTLs showed a very high effect under severe lowland reproductive-stage drought $\left(\mathrm{R}^{2}=16.3 \%\right.$ and $\left.30.7 \%\right)$. The rice grain yield QTL region on chromosome 2 was reported to contain QTLs for leaf rolling, leaf drying, canopy temperature, productive tiller number and stress recovery in this mapping population (Gomez et al., 2010). qDTY 3.1 , identified in a cross between Apo and Swarna population, expressed $31 \%$ of the genetic variance in lowland drought conditions. Two other QTLs, qDTY 1.1 and $\mathrm{qDTY}_{3.1}$, were identified for lowland drought conditions. qDTY $_{1.1}$ showed a constant effect in three different genetic backgrounds, Swarna, IR64 and MTU1010 with phenotypic variance up to 16.9\%. Babu et al., 2003 obtained double haploids rice lines and subjected it to water stress which results in identification of 47 drought related QTLs with phenotypic variation ranged from 5 to $59 \%$. Obara et al., 2010 mapped qRL $_{6.1}$ for root length under hydroponic conditions.

Yield QTLs which shows consistent effect in target environment over seasons has been identified on chromosomes 1, 4 and 6 could stabilize the productivity in high-yielding rice lines in a water-limited ecosystem. These yield QTLs governs secondary traits, such as leaf drying, canopy temperature, panicle harvest index and harvest index (Prince et al., 2015). Some of the QTLs combinations were also used to study the effect of their interactions with respect to reproductive stage drought stress. Combinations of $\mathrm{qDTY}_{1.1}$, $\mathrm{qDTY}_{2.1}, \mathrm{qDTY}_{3.1}, \mathrm{qDTY}_{11.1}$ were used and it was found that they give higher yield than normal in reproductive stage stress conditions (Sandhu et al., 2018).

\section{Problems in developing drought resistant rice}

In spite of the direct link with development issues, there has been little success in 
developing drought-tolerant rice cultivars though, conventional breeding for drought tolerance in rice has met little success (Fukai and Cooper, 1995). Some of the varieties has been developed by keeping focus on high grain yield but were never selected for drought tolerance (Kumar et al., 2008). Still today large part of rainfed ecosystems is planted with the varieties that were developed particularly for irrigated lowland ecosystems. These varieties need a continuous supply of water throughout the season and risk heavy yield loss if drought occurs (Dixit et al., 2014).The donors used in breeding programmes is linked with some undesirable traits and has also low yield potential. Several studies have been done to improve drought tolerance pre-breeding lines by crossing traditional drought-tolerant donors with drought susceptible varieties (Swamy and Kumar, 2013). This progress is further slowed down due to irregular timing, duration, severity of drought occurrence and difficulty of establishing screening environments. Hence, more number of breeding generations is required to develop drought resistant variety. Still, at present most of populations has been derived from intra specific crosses. Focus should also be given to go for inter specific crosses to explore novel alleles and their incorporation in to the breeding programs for drought tolerance in rice. It has also been found that when a rice plant is screened for drought stress then it affects its secondary traits which has direct effect on yield contributing traits like reduction of leaf area, restriction in opening of stomatal (Babu et al., 2003; Abbate et al., 2004; Lanceras et al., 2004).Focus should be given on selection of suitable secondary traits which are genetically associated with grain yield under drought conditions. It should be heritable and can be easily measurable but should not be associated with yield loss (Edmeades et al., 2001). However, selection for such types of traits is very difficult for critical situations like drought. Another reason for slow progress in breeding has been the failure to identify QTL with large and consistent effects that could be used for marker-assisted breeding. The most suitable QTL for drought would be one that can overcome QTL $\times$ genetic background, QTL $\times$ environment and QTL $\times$ ecosystem effects. To identify genomic regions with a consistent effect across environments, enormous mapping populations need to be screened in different environments. Further problem arises with the high cost which is to be incurred in genotyping and phenotyping of large mapping. Progress in mapping QTL for secondary traits associated with drought tolerance is studied (Bernier et al., 2008; Price and Courtois, 1999; Price et al., 2002) but marker assisted selection for such QTL has not been successfully used to improve yield under drought stress in rice. Some of the populations which has been developed by crossing CT9993 with IR62266 and IR64 with Azucenafor secondary drought-related traits (root morphology and osmotic adjustment) but few loci with large effects on either of these traits have been identified (Yadav et al., 1997; Hemamalini et al., 2000; Tripathy et al., 2000; Zheng et al., 2000; Zhang et al., 2001; Kamoshita et al., 2002; Babu et al., 2003). Last but not the least is the problems which areencountered with the QTLs which were having minor effect on the phenotype possess a great challenge for the breeders to discover major QTLs functioning independently to their genetic background (Gowda et al., 2011).

\section{References}

Abbate P.E., Dardanellib J.L., Cantareroc M.G., Maturanoc M., Melchiorid R.J.M. and Sueroa E.E. (2004). Climatic and water availability effects on water-use efficiency in wheat.Crop Science, 44: 474- 483. 
Afiukwa C.A., Faluyi J.O., Atkinson C.J., Ubi B.E., Igwe D.O. and Akinwale R.O. (2016). Screening of some rice varieties and landraces cultivated in Nigeria for drought tolerance based on phenotypic traits and their association with SSR polymorphisms. African Journal of Agricultural Research, 11(29): 25992615.

Ali M.L., Pathan M.S., Zhang J., Bai G., Sarkarung S. and Nguyen H.T. (2000). Mapping QTLs for root traits in a recombinant inbred population from two indica ecotypes in rice. Theoretical Applied Genetics, 101: 756-766.

Ali M.L., Sanchez P.L., Yu S., Lorieux M. and Eizenga G.C. (2010). Chromosome segment substitution lines: a powerful tool for the introgression of valuable genes from Oryza wild species into cultivated rice ( $O$. sativa L.). Rice, 3:218-234.

Anonymous, Annual report, G.O.I., 2016-17. http://agricoop.nic.in/sites/default/files/

Annual_rpt_201617_E.pdf

Anonymous, World Agricultural Production, USDA, October, 2016. http://apps.fas. usda.gov/psdonline/circulars/production .pdf

Aravind J., Kahani F. and Hittalmani S. (2015). Inter specific indica-japonica drought tolerant rice genotypes for aerobic condition. Journal of Rice Research, 3(4): 154.

Atkinson N.J. and Urwin P.E. (2012). The interaction of plant biotic and abiotic stresses: from genes to the field. Journal of Experimental Botany 63:3523-3543.

Babu R.C., (2010). Breeding for drought resistance in rice: an integrated view from physiology to genomics. Electronic Journal of Plant Breeding, 1(4): 1133-1141.

Babu R.C., Nguyen B.D., Chamarerk V., Shanmugasundaram P., Chezhian P.,
Jeyaprakash P., Ganesh S.K., Palchamy A., Sadasivam S., Sarkarung S., Wade L.J., and Nguyen H.T. (2003). Genetic analysis of drought resistance in rice by molecular markers: association between secondary traits and field performance. Crop Science, 43: 1457-1469.

Bargaz A., Zaman-Allah M., Farissi M., Lazali M., Drevon J.J., Maougal R.T. and Georg C. (2015). Physiological and molecular aspects of tolerance to environmental constraints in grain and forage legumes. International Journal of Molecular Science, 16:18976-19008.

Basnayake J., Fukai S. and Ouk M. (2006). Contribution of potential yield, drought tolerance and escape to adaptation of 15 rice varieties in rainfed lowlands in Cambodia. Proceedings of the Australian Agronomy Conference, Australian Society of Agronomy, Birsbane, Australia.

Bernier J., Atlin G.N., Serraj R., Kumar A. and Spaner D. (2008). Breeding upland rice for drought resistance. Journal of the Science of Food and Agriculture, 88(6): 927-939.

Bernier J., Kumar A., Venuprasad R., Spaner D. and Atlin G.N. (2007). A large-effect QTL for grain yield under reproductivestage drought stress in upland rice. Crop Science, 47: 507-516.

Bimpong I.K., Serraj R., Chin J.H., Ramos J., Mendoza E., Hernandez J., Mendioro M.S. and Brar D.S. (2011). Identification of QTLs for drought related traits in alien introgression lines derived from crosses of rice (Oryza sativa $\mathrm{cv}$. IR64) $\times O$. glaberrima under lowland moisture stress. Journal of Plant Biology, 54:237-250.

Boonjung H. and Fukai S. (1996) Effects of soil water deficit at different growth stages on rice growth and yield under upland conditions. 2. Phenology, 
biomass production and yield. Field Crops Research, 48: 47-55.

Bouman B.A.M., Humphreys E., Tuong T.P. and Barker R. (2007). Rice and water. In Advances in Agronomy, 92: 187-237. Collins N.C., Tardieu F. and Toberosa R. (2008). Quantitative trait loci and crop performance under abiotic stress: Where do we stand? Plant Physiology, 147: $469-486$.

Courtois B., McLaren G., Sinha P.K., Prasad K., Yadav R. and Shen L. (2000). Mapping QTLs associated with drought avoidance in upland rice. Molecular Breeding, 6: 55-66.

Courtois B., Shen L., Petalcorin W., Carandang S., Mauleon R. and Li Z. (2003). Locating QTLs controlling constitutive root traits in the rice population IAC $165 \times$ Co39. Euphytica, 134(3): 335-345.

Dey M.M. and Upadhyaya H.K. (1996). Yield loss due to drought, cold and submergence in Asia. In: Evenson, R.E., Herdt, R.W., Hossain, M. (Eds.), Rice Research in Asia: Progress and Priorities. Oxford University Press, Cary, NC, pp. 231-242.

Dixit S., Singh A., Cruz M.T.S., Maturan P.T., Amante M. and Kumar A. (2014). Multiple major QTL lead to stable yield performance of rice cultivars across varying drought intensities. $B M C$ Genetics, 15: 16.

Edmeades G.O., Cooper M., Lafitte R., Zinselmeier C., Ribaut J.M., Habben J.E., Löffler C. and Bänziger M. (2001) Abiotic stresses and staple crops. Proceedings of the Third International Crop Science Congress, August 18-23, 2000, Hamburg, Germany, CABI.

Ekanayake I.J., Steponkus P.L. and Dedatta S.K. (1990). Sensitivity of pollination to water deficits at anthesis in upland rice. Crop Science, 30: 310-315.
Evenson R.E. and Gollin D., (2003). Assessing the impact of the green revolution, 1960 to 2000. Science, 300: 758-762.

Farooq M., Wahid A., Lee D.J., Ito O. and Siddique K.H.M. (2009). Advances in Drought Resistance of Rice. Critical Reviews in Plant Science, 28:199-217.

Fukai S. and Cooper M. (1995). Development of drought-resistant cultivars using physiomorphological traits in rice. Field Crops Research, 40(2): 67-86.

Ghimire K.H., Quiatchon L.A., Vikram P., Swamy B.P.M., Dixit S., Ahmed H., Hernandez J.E., Borromeo T.H. and Kumar A. (2012). Identification and mapping of a QTL $\left(q D T Y_{1.1}\right)$ with a consistent effect on grain yield under drought. Field Crop Research, 131: 8896.

Gomez M.S., Boopathi N.M., Kumar S.S., Ramasubramanian T., Chengsong Z., Jeyaprakash P., Senthil A. and Babu R.C. (2010). Molecular mapping and location of QTLs for drought-resistance traits in indica rice (Oryza sativa L.) lines adapted to target environments. Acta Physiologiae Plantarum, 32: 355364.

Gowda V.R.P., Henry A., Yamauchic A., Shashidhar H.E. and Serraj R. (2011). Root biology and genetic improvement for drought avoidance in rice. Field Crops Research, 122(1): 1-13.

Ha P.T.T., Elzaawely A.A., Khanh T.D., Trung K.H. and Xuan T.D. (2016).Involvement of secondary metabolites in response to drought stress of rice (Oryza sativa L.). Agriculture, 6: 23.

Ha P.T.T., Khang D.T., Tuyen P.T., Minh L.T., Minh T.N., Lang N.T., Buu B.C., Xuan T.D. (2016). Correlation among agro-morphological variation and genetic diversity of rice (Oryza sativa 
L.) under drought stress. International Letters of Natural Sciences, 58: 42-53.

Haefele S.M. and Hijmans R.J. (2007). Soil quality in rice based rainfed lowlands of Asia: characterization and distribution. In :Aggarwal P.K., Ladha J.K., Singh R.K., Devakumar C., Hardy B. editors. Science, technology and trade for peace and prosperity. Proceedings of the $26^{\text {th }}$ International Rice Research Conference, 9-12 October 2006, New Delhi, India. Los Benos (Philippines and New Delhi (India), IRRI, ICAR and NAAS, pp 297-308.

He H. and Serraj R. (2012). Involvement of peduncle elongation, anther dehiscence and spikelet sterility in upland rice response to reproductive-stage drought stress. Environ. Exp. Bot., 75: 120-127.

Hemamalini G.S., Shashidar H.E. and Hittalmani S. (2000). Molecular marker-assisted tagging of morphological and physiological traits under two contrasting moisture regimes at peak vegetative stage in rice. Euphytica, 112: 69-78.

Henry A., Gowda V.R.P., Torres R.O., McNally K.L., Serraj R. (2011). Variation in root system architecture and drought response in rice (Oryza sativa): phenotyping of the Oryza SNP panel in rainfed lowland fields. Field Crops Research, 120: 205-214.

Horii H., Nemoto K., Miyamoto N. and Harada J. (2006). Quantitative trait loci for adventitious and lateral roots in rice (Oryza sativa L.). Plant Breeding, 125: 198- 200.

Huke R.E. and Huke E.H. (1997). Rice Area by Type of Culture: South, Southeast, and East Asia. International Rice Research Institute, Los Banos, Philippines.

Ikeda H., Kamoshita A. and Manabe T. (2007). Genetic analysis of rooting ability of transplanted rice (Oryza sativa
L.) under different water conditions. Journal of Experimental Botany, 58: 309-318.

Kamoshita A., Zhang J., Siopongco J., Sarkarung S., Nguyen H.T. and Wade L.J. (2002). Effects of phenotyping environment on identification of quantitative trait loci for rice root morphology under anaerobic conditions. Crop Science, 42: 255-265.

Kato Y., Abe J., Kamoshita A. and Yamagishi J. (2006). Genotypic variation in root growth angle in rice (Oryzasativa L.) and its association with deep root development in upland fields with different water regimes. Plant and Soil, 287: 117-129.

Kumar A., Bernier J., Verulkar S., Lafitte H.R. and Atlin G.N. (2008). Breeding for drought tolerance: direct selection for yield, response to selection and use of drought-tolerant donors in upland and lowland-adapted populations. Field Crops Research, 107: 221-231.

Kumar A., Dixit S., Ram T., Yadaw R.B., Mishra K.K. and Mandal N.P. (2014). Breeding high yielding drought-tolerant rice: genetic variations and conventional and molecular approaches. Journal of Experimental Botany, 65: 6265-6278.

Kumar A., Verulkar S.B., Mandal N.P., Variar M., Shukla V.D., Dwivedi J.L., Singh B.N., Singh O.N., Swain P., Mall A.K., Robin S., Chandrababu R., Jain A., Haefele S.M., Piepho H.P. and Raman A. (2012). High-yielding, drought-tolerant, stable rice genotypes for the shallow rainfed lowland drought-prone ecosystem. Field Crops Research, 133: 37-47.

Kumar R., Chattopadhyay T., Mandal S.S., Vati L. and Kumar M. (2018). Diversity analysis in maize through solubilityfractionated seed storage protein polymorphism. Vegetos, 31(1): 138145. 
Kumar R., Chattopadhyay T., Vati L., Mandal S.S. and Smriti (2016). Diversity analysis of maize inbred lines on the basis of morphological and simple sequence repeat markers. Ecology, Environment \& Conservation, 22: S147-S153.

Kumar R., Mandal S.S., Mishra A.K., Smriti, Singh R. and Kumar P. (2015). Heterosis and combining ability for yield and its contributing traits of kharif maize (Zea mays L.). The Bioscan, 10(4): 2049-2056.

Kumar R., Mishra A.K. and Smriti (2016). Correlation and path coefficient analysis between morphological traits affecting the grain yield and its associated traits in maize (Zea maysL.). The Bioscan, 11(2): 1003-1006.

Kumar R., Venuprasad R. and Atlin G.N. (2007). Genetic analysis of rainfed lowland rice drought tolerance under naturally-occurring stress in eastern India: heritability and QTL effects. Field Crops Research, 103: 42-52.

Kumar S., Dwivedi S.K., Haris A.A., Prakash V., Mondal S. and Singh S.K. (2015). Screening and identification of rice genotypes for drought tolerance at reproductive stage under rainfed lowland condition. Journal of AgriSearch, 2(2): 105-111.

Kumar S., Dwivedi S.K., Singh S.S., Bhatt B.P., Mehta P., Elanchezhian R., Singh V.P. and Singh O.N. (2014). Morphophysiological traits associated with reproductive stage drought tolerance of rice (Oryza sativa L.) genotypes under rain-fed condition of eastern IndoGangetic Plain. Indian Journal of Plant Physiology, 19(2): 87-93.

Kumar S., Dwivedi S.K., Singh S.S., Jha S.K., Lekshmy S., Elanchezhian R., Singh O.N. and Bhatt B.P. (2014). Identification of drought tolerant rice genotypes by analysing drought tolerance indices and morphophysiological traits. SABRAO Journal of Breeding and Genetics, 46(2): 217-230.

Lafitte H.R., Champoux M.C., McLaren G. and O'Toole J.C. (2001). Rice root morphological traits are related to isozyme group and adaptation. Field Crops Research, 71: 57-70.

Lafitte H.R., Yongsheng G., Yan S. and Li Z.K. (2007). Whole plant responses, key processes, and adaptation to drought stress: the case of rice. Journal of Experimental Botany, 58: 169-175.

Lafitte R.H., Ismail A.M. and Bennett J. (2006) Abiotic stress tolerance in tropical rice: progress and the future. Oryza. 43: 171-186.

Lanceras J.C., Pantuwan G., Jongdee B. and Toojinda T. (2004). Quantitative trait loci associated with drought tolerance at reproductive stage in rice. Plant Physiology, 135: 384-399.

Lilley J.M. and Fukai S. (1994). Effect of timing and severity of water deficit on four diverse rice cultivars. I. Rooting pattern and soil water extraction. Field Crops Research, 37: 205-213.

Lilley J.M., Ludlow M.M., McCouch S.R. and O'Toole J.C. (1996). Locating QTL for osmotic adjustment and dehydration tolerance in rice. Journal of Experimental Botany, 47: 1427-1436.

Mackill D.J., Coffman W.R. and Garrity D.P. (1996). Rainfed Lowland Rice Improvement. International Rice Research Institute, Manila, Philippines, p. 242.

Mackill D.J., Ismail A.M., Singh U.S., Labios R.V. and Paris T.R. (2012) Development and rapid adoption of submergence-tolerant $(S u b 1)$ rice varieties. Advances in Agronomy, 115: 303-356.

Maclean J.L., Dawe D.C., Hardy B. and Hettel G.P. (2002). Rice Almanac. Los Banos, Philippines; International Rice 
Research Institute, Bouake, Cote d'Ivoire; West Africa Rice Department Association, Cali, Columbia; International Center for Tropical Agriculture, Rome, Italy; Food and Agriculture Organization, pp. 253.

Mandal N.P., Sinha P.K., Variar M., Shukla V.D., Perraju P., Mehta A., Pathak A.R., Dwivedi J.L., Rathi S.P.S., Bhandarkar S., Singh B.N., Singh D.N., Panda S., Mishra N.C., Singh Y.V., Pandya R., Singh M.K., Sanger R.B.S., Bhatt J.C., Sharma R.K., Raman A., Kumar A. and Atlin G.N. (2010). Implications of genotype $\mathrm{x}$ input interactions in breeding superior genotypes for favorable and unfavorablerainfed upland environments. Field Crops Research, 118: 135-144.

McCouch S.R., Kochert G., Yu Z.H., Wang Z.Y., Khush G.S., Coffman W.R. and Tanksley S.D. (1988). Molecular mapping of rice nuclear genome. $T A G$, 76(6): 815-829.

Mishra A.K., Kumar A., Kumar R., Kumari H., Adarsh A., Rangare N.R. and Singh R. (2015). Assessment of genetic variability for yield and yield attributing traits in rice (Oryzasativa L.) under Allahabad Agro-climatic region. Trends in Biosciences, 8(15): 3948-3952.

Mishra A.K., Kumar A., Rangare N.R., Kumar R. and Singh R. (2015). Genetic association for grain yield and its component traits in indigenous and exotic rice accessions. The Ecoscan, 9(1 \& 2): 461-465.

Mishra K.K., Vikram P., Yadaw R.B., Swamy B.P.M., Dixit S., Cruz M.T.S., Maturan P., Marker S. and Kumar A. (2013). qDTY12.1: a locus with a consistent effect on grain yield under drought in rice. BMC Genetics, 14: 12.

Mohan M., Nair S., Bhagwat A., Krishna T.G., Yano M., Bhatia C.R. and Sasaki
T., 1997, Genome mapping, molecular markers and marker-assisted selection in crop plants. Molecular Breeding, 3(2): 87-103.

Nguyen H.T., Babu R.C. and Blum A. (1997). Breeding for drought tolerance in rice: physiology and molecular genetics considerations. Crop Science, 37: 14261434.

O’Toole J. C. and Namuco O.S. (1983). Role of panicle exsertion in water stress induced sterility. Crop Science, 23: 1093-1097.

Obara M., Tamura W., Ebitani T., Yano M., Sato T. and Yamaya T. (2010). Finemapping of qRL6.1, a major QTL for root length of rice seedlings grown under a wide range of $\mathrm{NH} 4+$ concentrations in hydroponic conditions, TAG, 121(3): 535-547.

Palanog A.D., Mallikarjuna Swamy B.P., Shamsudin N.A.A., Dixit S., Hernandez J.E., Boromeo T.H., Sta Cruz P.C., Kumar A. (2014). Grain yield QTLs with consistent-effect under reproductive-stage drought stress in rice. Field Crops Research, 161: 46-54.

Pandey S., Bhandari H. and Hardy B., (Eds.) (2007). Economic costs of drought and rice farmers' coping mechanisms: a cross-country comparative analysis from Asia, International Rice Research Institute (IRRI). Los Banos, Philippines, 203

Pandey S., Bhandari H., Sharan R., Naik D., Taunk S.K. and Sastri A.S.R.A.S. (2005). Economic Costs of Drought and Rainfed Rice Farmers' Coping Mechanisms in Eastern India. Final Project Report. International Rice Research Institute, Los Banos, Philippines.

Pantuwan G., Fukai S., Cooper M., Rajatasereekul S. and O'Toole J.C. (2002) Yield response of rice (Oryza sativa L.) to drought under rainfed 
lowlands: 3. plant factors contributing to drought resistance. Field Crops Research, 73: 181-200.

Price A.H. and Courtois B. (1999). Mapping QTLs associated with drought resistance in rice: progress, problems and prospects. Plant Growth Regulation, 29: 123-133.

Price A.H. and Tomos A.D. (1997). Genetic dissection of root growth in rice (Oryza sativa L.) II: mapping quantitative trait loci using molecular markers. Theoretical and Applied Genetics, 95:143-152.

Price A.H., Cairns J.E., Horton P., Jones R.G.W. and Griffiths H. (2002). Linking drought-resistance mechanisms to drought avoidance in upland rice during a QTL approach: progress and new opportunities to integrate stomatal and mesophyll responses. Journal of Experimental Botany, 53: 989-1004.

Price A.H., Steele K.A., Moore B.J., Barraclough P.B. and Clark L.J. (2000). A combined RFLP and AFLP map of upland rice (Oryza sativa L.) used to identify QTL for root-penetration ability. Theoretical and Applied Genetics, 100: 49-56.

Prince S.J., Beena R., Gomez S.M., Senthivel S. and Babu R.C. (2015). Mapping consistent rice (Oryza sativa L.) yield qtls under drought stress in target rainfed environments. Rice, 8: 25.

Sabar M. and Arif M. (2014). Phenotypic response of rice (Oryza sativa) genotypes to variable moisture stress regimes. International Journal of Agriculture \& Biology, 16: 32-40.

Saikumar S., Gouda P.K., Saiharini A., Varma C.M.K., Vineesha O., Padmavathi G. and Shenoy V.V. (2014). Major QTL for enhancing rice grain yield under lowland reproductive drought stress identified using an $O$. sativa / $O$. glaberrima introgression line. Field Crops Research, 163: 119131.

Saini H.S. (1997). Effects of water stress on male gametophyte development in plants. Sexual Plant Reproduction, 10(2): 67-73.

Saini H.S. and Westgate M.E. (2000). Reproductive development in grain crops during drought. Advances in Agronomy, 68: 59-96.

Saini H.S., Sedgley M. and Aspinall D. (1983). Effect of heat-stress during floral development on pollen-tube growth and ovary anatomy in wheat (Triticum aestivum L.). Australian Journal of Plant Physiology, 10: 137144.

Salunkhe A.S., Poornima R., Prince K.S., Kanagaraj P., Sheeba J.A., Amudha K., Suji K.K., Senthil A. andBabu R.C. (2011). Fine mapping QTL for drought resistance traits in rice (Oryza sativa L.) using bulk segregant analysis. Molecular Biotechnology, 49:90-95.

Sandhu N., Dixit S., Swamy B.P.M., Vikram P.,Venkateshwarlu C., Catolos M. and Kumar A. (2018). Positive interactions of major-effect QTLs with genetic background that enhances rice yield under drought. Scientific Reports, 8: 1626.

Sandhu N., Singh A., Dixit S., Cruz M.T.S., Maturan P.C., Jain R.K. and Kumar A. (2014). Identification and mapping of stable QTL with main and epistasis effect on rice grain yield under upland drought stress. BMC Genetics, 15: 63.

Satake T. and Yoshida S. (1978). High temperature-induced sterility in indica rice at flowering. Japanese Journal of Crop Science, 47: 6-17.

Sellamuthu R., Liu G.F., Babu R.C. and Serraj R. (2011). Genetic analysis and validation of quantitative trait loci associated with reproductive-growth traits and grain yield under drought 
stress in a doubled haploid line population of rice (Oryza sativa L.). Field Crops Research, 124: 46-58.

Sellamuthu R., Ranganathan C. and Serraj R. (2015). Mapping qtls for reproductivestage drought resistance traits using an advanced backcross population in upland rice. Crop Science, 55:1-13.

Serraj R. and Sinclair T.R. (2002). Osmolyte accumulation: can it really help increase crop yield under drought conditions? Plant Cell Environ, 25(2): 333-341.

Serraj R., Allen H.L. and Sinclair T.L. (1999). Soybean leaf growth and gas exchange response to drought under carbon dioxide enrichment. Global Change Biology, 5: 283-292.

Serraj R., McNally K.L., Slamet-Loedin I., Kohli A., Haefele S.M., Atlin G. and Kumar A. (2011). Drought resistance improvement in rice: an integrated genetic and resource management strategy. Plant Production Science, 14(1): 1-14.

Shamsudin N.A.A., Swamy B.P.M., Ratnam W., Cruz M.T.S., Sandhu N., Raman A.K. and Kumar A. (2016). Pyramiding of drought yield QTLs into a high quality Malaysian rice cultivar MRQ74 improves yield under reproductive stage drought. Rice, 9: 21.

Singh S., Mackill D.J. and Ismail A.M. (2009). Responses of Sub1 rice introgression lines to submergence in the field: yield and grain quality. Field Crops Research, 113: 12-23.

Smriti, Singh S.P., Kumar M., Verma R.K., Kumar R. and Neha K. (2015). Character association and path coefficient analysis for yield and its component traits in rice landraces of Bihar. The Bioscan, 10(4): 2151-2154.

Specht J.E., Chase K., Macrander M., Graef G.L., Chung J., Markwell J.P., Germann M., Orf J.H. and Lark K.G. (2001). Soybean response to water: a QTL analysis of drought tolerance. Crop Science, 41: 493-509.

Srividhya A., Vemireddy L.R., Sridhar S., Jayaprada M., Ramanarao P.V., Hariprasad A.S., Reddy H.K., Anuradha G. and Siddiq E. (2011). Molecular mapping of QTLs for yield and its components under two water supply conditions in rice (Oryza sativa L.). Journal of Crop Science and Biotechnology, 14(1): 45-56.

Steele K.A., Price A.H., Shashidar H.E. and Witcombe J.R. (2006). Marker-assisted selection to introgress rice QTLs controlling root traits into an Indian upland rice variety. TAG, 112(2): 208221.

Suji K.K., Biji K.R., Poornima R., Prince K.S., Amudha K., Kavitha S., Mankar S. and Babu R.C. (2011). Mapping QTLs for plant phenology and production traits using indica rice (Oryza sativa L.) lines adapted to rainfed environment. Molecular Biotechnology, 52: 151-160.

Swamy B.P.M. and Kumar A. (2013) Genomics-based precision breeding approaches to improve drought tolerance in rice. Biotechnology Advances, 31(8): 1308-1318.

Swamy B.P.M., Ahmed H.U., Henry A., Mauleon R., Dixit S., Vikram P., Tilatto R., Verulkar S.B., Perraju P., Mandal N.P., Variar M., Robin S., Chandrababu R., Singh O.N., Dwivedi J.L., Das S.P., Mishra K.K., Yadaw R.B., Aditya T.L., Karmakar B., Satoh K., Moumeni A., Kikuchi S., Leung H., Kumar A. (2013). Genetic, physiological, and gene expression analyses reveal that multiple QTL enhance yield of rice mega-variety IR64 under drought. Plos one, 8(5): e62795.

Temnykh S., Park D.W., Ayres N., Cartinhour S., Hauck N., Lipovich L., Cho Y.G., Ishii T., and McCouch S.R. (2000). 
Mapping and genome organization of microsatellite sequences in rice (OryzasativaL.). TAG, 100(5): 697-712. Thomson M.J., de Ocampo M., Egdane J., Rahman M.R., Sajise A.G., Adorada D.L., Tumimbang-Raiz E., Blumwald E., Seraj Z.I., Singh R.K., Gregorio G.B. and Ismail A.M. (2010) Characterizing the Saltol quantitative trait locus for salinity tolerance in rice. Rice, 3: 148-160.

Tripathy J.N., Zhang J., Robin S., Nguyen T.T. and Nguyen H.T. (2000) QTLs for cell-membrane stability mapped in rice (Oryza sativa L.) under drought stress. Theoretical and Applied Genetics, 100: 1197-1202.

Usman M., Raheem Z.F., Ahsan T., Iqbal A., Sarfaraz Z.N. and Haq Z. (2013). Morphological, physiological and biochemical attributes as indicators for drought tolerance in rice (Oryza sativa L.). European Journal of Biological Sciences, 5(1): 23-28.

Venuprasad R., Bool M.E., Dalid C.O., Zhao D., Espiritu M., Cruz M.T.S., Amante M., Kumar A. andAtlin G.N. (2009) Genetic loci responding to two cycles of divergent selection for grain yield under drought stress in a rice breeding population. Euphytica, 167: 261-269.

Venuprasad R., Cruz M.T.S., Amante M., Magbanua R., Kumar A. and Atlin G.N. (2008). Response to two cycles of divergent selection for grain yield under drought stress in four rice breeding populations. Field Crops Research, 107: 232-244.

Venuprasad R., Dalid C.O., Del Valle M., Zhao D., Espiritu M., Cruz M.T.S., Amante M., Kumar A. and Atlin G.N. (2009). Identification and characterization of large effect quantitative trait loci for grain yield under lowland drought stress in rice using bulk-segregant analysis.
Theoretical and Applied Genetics, 120: 177-190.

Venuprasad R., Lafitte H.R. and Atlin G.N. (2007). Response to direct selection for grain yield under drought stress in rice. Crop Science, 47: 285-293.

Verulkar S.B., Mandal N.P., Dwivedi J.L., Singh B.N., Sinha P.K., Mahato R.N., Swain P., Dongre P., Payasi D., Singh O.N., Bose L.K., Robin S., Babu R.C., Senthil S.J., Shashidhar H.E., Hittalmani S., Vera Cruz C., Paris T., Hijsman R., Raman A., Haefele S., Serraf R., Atlin G.N. and Kumar A. (2010). Breeding resilient and productive rice genotypes adapted to drought-prone rainfed ecosystems of India. Field Crops Research, 117: 197208.

Vikram P., Kadam S., Singh B.P., Lee Y.J., Pal J.K., Singh S., Singh O.N., Swamy B.P.M., Thiyagarajan K., Singh S. and Singh N.K. (2016). Genetic diversity analysis reveals importance of green revolution gene ( $s d l$ locus) for drought tolerance in rice. Agricultural Research, 5(1): 1-12.

Vikram P., Swamy B.P.M., Dixit S., Ahmed H., Cruz M.T.S., Singh A.K., Ye G. and Kumar A. (2012) Bulk segregant analysis: "An effective approach for mapping consistent-effect drought grain yield QTLs in rice". Field Crops Research, 134:185-192.

Vikram P., Swamy B.P.M., Dixit S., Ahmed H.U., Cruz M.T.S., Singh A.K., Kumar A. (2011). $q D T Y 1.1$, a major QTL for rice grain yield under reproductivestage drought stress with a consistent effect in multiple elite genetic backgrounds. BMC Genetics, 12: 89.

Vikram P., Swamy B.P.M., Dixit S., Trinidad J., Cruz M.T.S., Maturan P.C., Amante M. and Kumar A. (2016). Linkages and interactions analysis of major effect 
drought grain yield qtls in rice. Plos one, 11(3): $\mathrm{e} 0151532$.

Yadav R., Courtois B., Huang N. and Mclaren G. (1997) Mapping genes controlling root morphology and root distribution in a double haploid population of rice. Theoretical and Applied Genetics, 94: 619-632.

Yadaw R.B., Dixit S., Raman A., Mishra K., Vikram P., Swamy B.P.M., Cruz M.T.S., Maturan P., Pandey M. and Kumar A. (2013). A QTL for high grain yield under lowland drought in the background of popular rice variety Sabitri from Nepal. Field Crops Research, 144: 281-287.

Yang J.C., Liu K., Zhang S.F., Wang X.M., Zh Q., Wang X.M. and Liu L.J. (2008).
Hormones in rice spikelets in responses to water stress during meiosis. Acta Agronomica Sinica, 34: 111-118.

Zhang J., Zheng H.G., Aarti A., Pantuwan G., Nguyen T.T., Tripathy J.N., Sarial A.K., Robin S., Babu R.C., Nguyen B.D., Sarkarung S., Blum A. and Nguyen H.T. (2001). Locating genomic regions associated with components of drought resistance in rice: comparative mapping within and across species. Theoretical and Applied Genetics, 103: 19-29.

Zheng H., Babu R.C., Pathan M.S., Ali L., Huang N., Courtois B. and Nguyen H.T. (2000). Quantitative trait loci for rootpenetration ability and root thickness in rice: comparison of genetic backgrounds. Genome, 43: 53-61.

\section{How to cite this article:}

Rishav Kumar. 2018. Development of Drought Resistance in Rice. Int.J.Curr.Microbiol.App.Sci. 7(05): 1439-1456. doi: https://doi.org/10.20546/ijcmas.2018.705.171 